\title{
Tumor necrosis factor-alpha production induced by peptidoglycan-polysaccharide in early pregnant ewes
}

\author{
Gabrielle Marie Rogers \\ West Virginia University
}

Follow this and additional works at: https://researchrepository.wvu.edu/etd

\section{Recommended Citation}

Rogers, Gabrielle Marie, "Tumor necrosis factor-alpha production induced by peptidoglycanpolysaccharide in early pregnant ewes" (2006). Graduate Theses, Dissertations, and Problem Reports. 4261.

https://researchrepository.wvu.edu/etd/4261

This Thesis is protected by copyright and/or related rights. It has been brought to you by the The Research Repository @ WVU with permission from the rights-holder(s). You are free to use this Thesis in any way that is permitted by the copyright and related rights legislation that applies to your use. For other uses you must obtain permission from the rights-holder(s) directly, unless additional rights are indicated by a Creative Commons license in the record and/ or on the work itself. This Thesis has been accepted for inclusion in WVU Graduate Theses, Dissertations, and Problem Reports collection by an authorized administrator of The Research Repository @ WVU. For more information, please contact researchrepository@mail.wvu.edu. 
Tumor Necrosis Factor- Alpha Production Induced by Peptidoglycan-Polysaccharide in Early Pregnant Ewes

Gabrielle Marie Rogers

Thesis submitted to the

Davis College of Agriculture, Forestry and Consumer Sciences

at West Virginia University

in Partial Fulfillment of the Requirements

for the Degree of

Master of Science

in

Reproductive Physiology

Robert A. Dailey, PhD, Chair

E. Keith Inskeep, PhD

Michael W. Vernon, PhD

Division of Animal and Veterinary Sciences

Morgantown, West Virginia

2006

Keywords: Peptidoglycan-Polysaccharide, Inflammation, Acute Phase

Response, TNF- a, Embryonic loss, Sheep 


\begin{abstract}
TNF- $\alpha$ Production Induced by Peptidoglycan-Polysaccharide in Early Pregnant Ewes
\end{abstract}

\title{
Gabrielle Marie Rogers
}

Peptidoglycan-polysaccharide (PG-PS), cell wall component of gram-positive bacteria, was used to intoxicate sheep to study mastitis-related reproductive failure, mediated by TNF- $\alpha$. Estrus was synchronized in ten adult Suffolk ewes. Four days after mating (Day 0 ) the jugular and posterior vena cava (saphenous vein) were catheterized. On Day 5, ewes were assigned randomly to either: control group $(\mathrm{n}=4,0.9 \% \mathrm{NaCl})$, or PG-PS group $(\mathrm{n}=6,30 \mu \mathrm{g} / \mathrm{kg} \mathrm{BW}$, i.v.). Plasma samples were collected from both jugular and saphenous vein catheters every 15 minutes for 6 hours. Radioimmunoassay quantified concentrations of TNF- $\alpha$. Data were analyzed using repeated-measures analysis of variance. Intoxication of day-5 pregnant ewes with $30 \mu \mathrm{g} / \mathrm{kg}$ BW PG-PS induced significant $(p<0.0021)$ increases in TNF $\alpha$ concentration in the venous blood draining the reproductive tract (posterior vena cava), but not in jugular blood, demonstrating that injection of PG-PS systemically leads to local production of the inflammatory cytokine, TNF- $\alpha$. 


\section{Table of Contents}

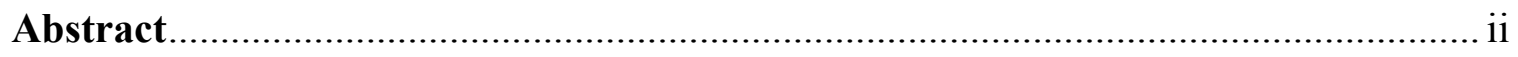

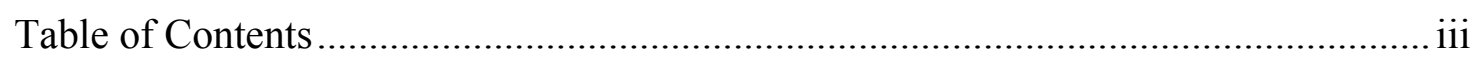

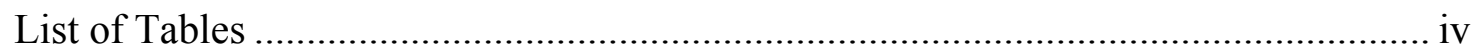

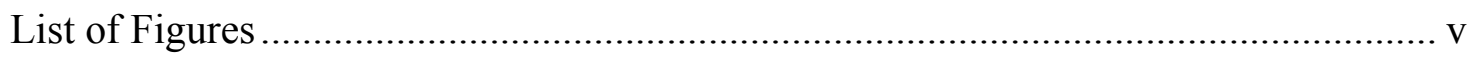

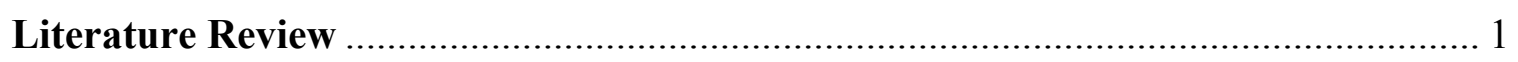

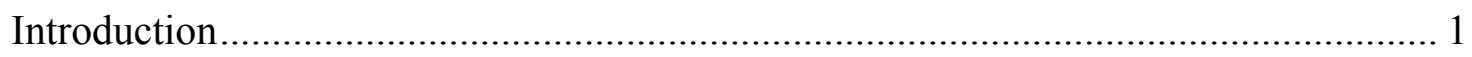

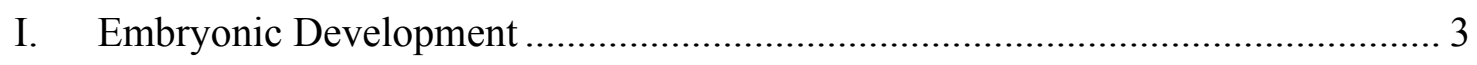

A. Morphological Events .................................................................................. 3

B. Endocrinology of Early Embryonic Development …….................................... 5

II. Mammary Gland Growth and Endocrinology ..................................................... 6

III. Characteristics of Mastitis........................................................................... 7

IV. Peptidoglycan-Polysaccharide Complex Characteristics......................................... 9

V. Innate Immune System and the Toll-like Receptor Pathway............................... 10

VI. Cytokines and Acute Phase Proteins.................................................................. 13

VII. Immunology of Maternal-fetal Interface ………................................................ 16

VIII.Pregnancy Loss Due to Endotoxin and Peptidoglycan ........................................ 17

A. Endotoxin-Induced Pregnancy Loss ……………………………………...... 17

B. Peptidoglycan-Induced Pregnancy Loss .......................................................... 19

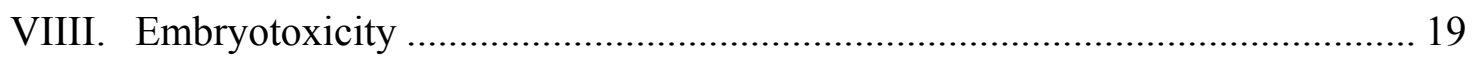

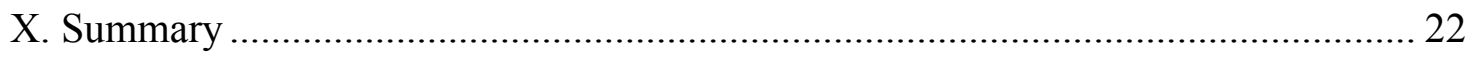

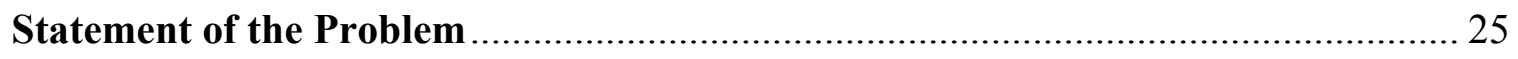

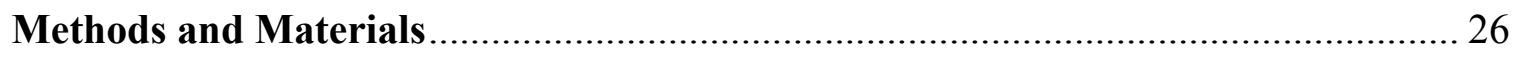


I. Synchronization Protocol for Ewes .............................................................. 26

II. Catheter Construction and Placement (Day 4 of gestation) ............................... 26

III. Preparation of PG-PS/ NaCL, Assignment of Treatments, and Blood Collection

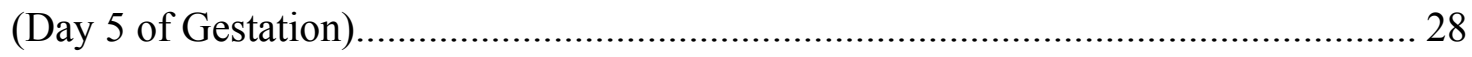

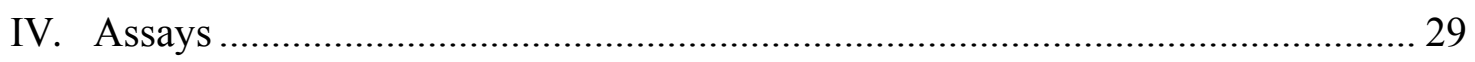

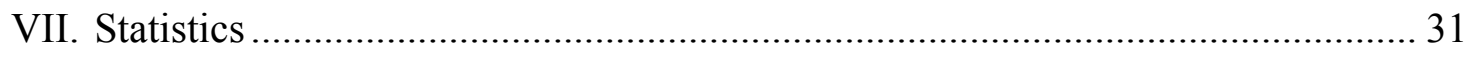

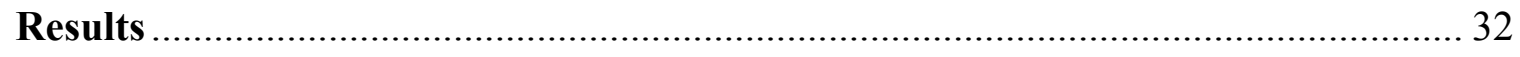

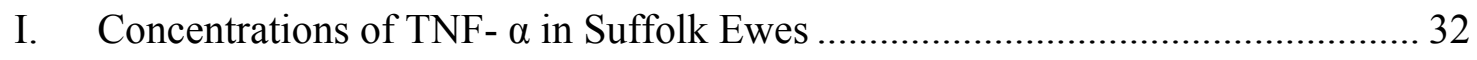

II. Concentrations of Serum Amyloid A in Suffolk Ewes...................................... 33

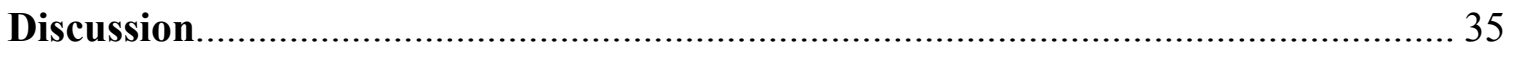

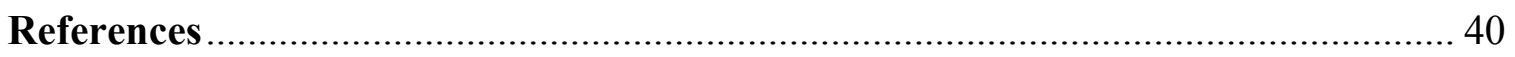




\section{List of Tables}

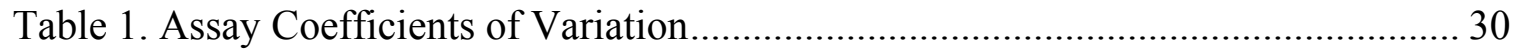




\section{List of Figures}

Figure 1. Progesterone Profiles of Posterior Vena Caval ................................................... 31

Figure 2. Concentrations of TNF- $\alpha$ in Plasma from Posterior Vena Cava ........................ 32

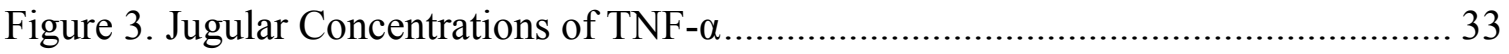

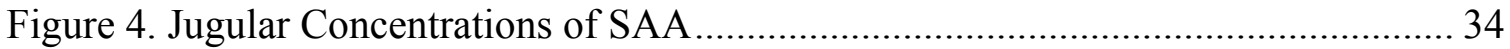




\section{Literature Review}

\section{Introduction}

Breeding efficiency in dairy cows can be reduced at multiple levels: timing of ovulation, failure to ovulate, failure to manifest estrus, viability of gametes, embryonic survival, and fetal development (Stott and Williams, 1962). Inskeep and Dailey (2005) stated that estimated embryonic death at day 3 after insemination would be $33 \%$ of, and further embryonic death would occur in $15 \%$ of, first inseminations. It has become widely accepted that much of the pregnancy loss in cattle is due to early embryonic death, wherein embryos are most susceptible to mortality during development from the morula to blastocyst stage on days 5 through 8 . In multiparous cows, $67 \%$ of embryonic loss occurred by day 8 , whereas $92 \%$ of the estimated loss was seen by day 8 in nulliparous females (Inskeep and Dailey, 2005). Thatcher et al. (1994) concluded that approximately $30 \%$ of repeat breeder cows experienced embryonic loss by day 7 of pregnancy. Repeat breeding ewes tend to have similar losses (Quinlivan et al., 1966).

"Abortions during early pregnancy result in increased days open at a cost of at least US $\$ 2.00$ to $\$ 5.00$ per day. An early pregnancy loss causing an increase of 45 days open may result in a loss of between $\$ 90$ and $\$ 225$. If $20 \%$ of a 200 cow herd abort[s], the loss could be as much as $\$ 4500 "$ (Kirk, 2006). The associated risk is an extended calving interval which reduces production. By increasing the calving interval from 12 to 13 months, there is a $2-5 \%$ loss in the beef herd's potential calf production, and calving intervals of over 14 months will produce losses of greater than $10 \%$ in average producing dairy herds (Kirk, 2006). Louca and Legates (1968) stated that yield per unit of time; i.e. milk per day or per year is more important than total lactation production; days open 
caused a decrease of $2.40 \pm 1.09 \mathrm{~kg}$ of milk and $0.112 \pm 0.040 \mathrm{~kg}$ of fat for each additional day open. Although there is general agreement that calving interval should be approximately 12 months, many believe that the length of the calving interval should depend on the age of the cow and her producing ability and should not be the same for all cows. Maximizing conception rates at the first insemination postpartum will accomplish this task (Leslie et al., 1986).

Alarmingly, pregnancy rates in dairy cattle have decreased from $50-60 \%$ in the 1970s to $35-45 \%$ (Hansen et al., 2004). One hypothesized cause of these losses is that an onset of infection due to bacteria and multiple other environmental factors results in embryonic loss. The innate immune system is poised to recognize and respond to the earliest stages of infection. Because pathogens differ greatly in their structures and means of pathogenesis, the host's innate immune system must have diverse ways of dealing with all types of pathogens (Janeway et al., 2001). A key component of the host innate immune response is up-regulation of cytokine production. The well-described proinflammatory cytokine, tumor necrosis factor alpha (TNF- $\alpha$ ), mediates the inflammatory response at both local and systemic levels (Bannerman et al., 2004). Production of TNF- $\alpha$ has been implicated in direct actions mediating embryonic loss (Stewart et al., 2003), and indirect actions (Erlenbacher et al., 2004) wherein TNF- $\alpha$ alters physiological concentrations of reproductive hormones necessary for gestation. 


\section{Embryonic Development}

\section{A. Morphological Events}

A mammalian oocyte is a large haploid cell surrounded by a protective extracellular layer, the zona pellucida, and by granulosal cells organized into the corona radiata. Entry of the oocyte into meiosis in the fetal ovary is accompanied by DNA synthesis analogous to $\mathrm{S}$ phase in mitotic cells. Meiosis proceeds up to the first prophase and is arrested, just prior to or shortly after birth in most mammals. After puberty, meiosis is reinitiated, and oocytes complete the first meiotic division with formation of the first polar body. They become arrested at second metaphase of meiosis until completion of the second meiotic division is triggered by sperm penetration at fertilization (Dekel, 1998) in the ampulla of the oviduct (Dalton et al., 1994). After fusion of the sperm and oocyte, the diploid chromosome number is restored, and a complex program of gene activity directs embryogenesis (Blandau, 1961, Schatten, 1998).

Cleavage in mammals consists of a series of mitotic divisions spaced at approximately 12-hour intervals. The cell divisions during cleavage are unusual in that no cellular growth occurs between successive divisions. Early cleavage in mammals occurs while the embryo is in the oviduct and still in the zona pellucida. During the first cleavage, two identical cells, blastomeres, are produced. Initiation of gene transcription from the zygotic genome occurs at this stage in the mouse embryo, whereas in other species maternal factors (mRNA and proteins) control early embryonic development as the onset of zygotic transcription is delayed. Every subsequent cell division is asynchronous. At the eight cell stage, cells flatten, become compact, and increase cell to cell adhesion via structures known as tight junctions. At this stage, morula, the embryo 
organizes the cells into the inner cell mass and the outer cell mass (trophoblast). At the thirty-two cell stage, the embryo enters the uterus. Between the thirty-two and sixty-four cell stage, now termed a blastocyst, the outer trophoblast layer differentiates and transports fluid from the outside to the inside of the embryo; this fluid filled cavity is called the blastocoel. As the cells of the blasocyst continue to divide (64 -128 cell stage), the blastocoel fills with fluid and the enzymatic activity along with pressure exerted by the expansion permits the embryo to escape the zona pellucida, termed hatching. The embryo settles onto the epithelium that lines the uterus, triggering the implantation process (Burdsal, 1998).

After hatching the conceptus undergoes massive growth. At day 13 in the cow, the blastocyst is $3 \mathrm{~mm}$ in diameter, and during the next 4 days the blastocyst will grow to $250 \mathrm{~mm}$ in length. In domesticated animals, the preattachment period is long. During this time, extensive extraembryonic membranes are formed by a fusing process that generates the amnion, chorion, and allantochorion. The pig, sheep, and cow have a filamentous or threadlike blastocyst prior to attachment. Formation of the extraembryonic membranes is an obligatory step in the embryo's ability to attach to the uterus of the dam. The trophoblast, along with primitive endoderm and mesoderm, gives rise to the chorion and the amnion. The yolk sac develops from the primitive endoderm. The chorion will eventually attach to the uterus, while the amnion will provide a fluidfilled protective sac for the developing fetus. In the cow and sheep, the conceptus does not implant or bury itself, but rather attaches to the endometrial surface. The chorionic villi, small finger-like projections that are on the surface of the chorion, attach to the maternal caruncular tissue in the endometrium of the dam (Senger, 1999). 


\section{B. Endocrinology of Early Embryonic Development}

Progesterone secretion by the corpus luteum (CL) must be maintained at sufficiently high rates so that attachment can occur. The embryo enters the uterus between days 2 and 5 after ovulation; a critical series of events including the conceptus signaling to the dam, and maternal recognition of pregnancy must occur to prevent concentrations of progesterone from decreasing. As reviewed by Goodman and Inskeep (2006), in ewes and cows progesterone from one cycle and the subsequent rise in estrogen at estrus prevent premature release of PGF2- $\alpha$ in the next cycle. As reviewed by Senger (1999), the CL of ruminants produces oxytocin which stimulates endometrial cells to synthesize prostaglandin (PGF2- $\alpha$ ) and initiate luteolysis. The production of PGF2- $\alpha$ is dependant on the number of oxytocin receptors on the endometrial cells during the estrous cycle. When these receptors are available in sufficient numbers, secretion of PGF2- $\alpha$ and luteolysis occur. However, data reviewed by Goodman and Inskeep (2006) cast doubt on the requirement for luteal oxytocin in luteal regression in ruminants. They cite that depletion of oxytocin from bovine CL before luteolysis had no effect on duration of the estrous cycle, and oxytocin did not stimulate secretion of PGF2- $\alpha$ by endometrial explants from either cyclic or pregnant cows on day 17 post-estrus. Treatment of ovariectomized ewes with progesterone and estrogen (mimicking the luteal phase) caused a release of platelet-activating factor (PAF) into the uterine lumen; exogenous PAF stimulated secretion of PGF2- $\alpha$, as measured by PGFM (Chami et al., 1999). Goodman and Inskeep (2006) speculated that the synergism of PAF and oxytocin could account for the high amplitude of secretion of PGF2- $\alpha$ during luteolysis in the ewe.

In the ewe and cow, the free floating blastocyst produces specific proteins that signal the prevention of luteolysis; these proteins belong to a class known as interferon, 
mostly nonspecific glycoprotein produced by leukocytes, fibroblasts, lymphocytes, and trophoblastic cells. Ovine and bovine interferon-tau binds to the endometrium and inhibits oxytocin receptor synthesis by endometrial cells. In addition to blocking oxytocin receptors, interferon-tau binds to the apical portion of the uterine glands and promotes protein synthesis, which is believed to be critical for embryonic survival. In the sheep, maternal recognition occurs on days 13-14 after ovulation and attachment on day 15-18 occur (Senger, 1999).

Paria et al. (2001) stated that in mice and rats there seems to be no evidence that estrogen and/or progesterone act directly on the preimplantation embryo; embryonic development is considered to depend on growth-promoting factors originating from the reproductive tract under the influence of these hormones. However, normal development in defined media in cultures indicates that preimplantation embryos themselves produce growth promoting factors and cytokines. Dalton et al. (1994) showed that several growth factors can exert pleiotropic effects during preimplantation of the mouse embryo; and suggested that oviductal growth factors and embryo-derived growth factors contribute to an optimal environment for preimplantation embryonic development.

\section{Mammary Gland Growth and Endocrinology}

Between onset of puberty and pregnancy, the mammary gland grows disproportionately faster than normal body growth, known as allometric growth. During the first several estrous cycles, under the influence of estrogen, the mammary duct increases in diameter. Under the influence of progesterone the terminal portions of each branch form functional secretory elements - alveoli. Prolactin and growth hormone (somatotropin) promote further development of the alveoli, and complete development of 
the mammary gland occurs during the last trimester of pregnancy when the terminal alveoli grow into [bunches called] lobules (Senger, 1999). Prolactin, adrenal cortical hormones, and placental lactogen are important in allowing the mammary epithelium to synthesize milk (Akers, 2000). Milk ejection, the active transfer of milk from the alveoli and alveolar ducts into the larger mammary ducts, cisterns, and teat, is a neuroendocrine reflex usually requiring suckling by the neonate (or mechanical stimulation) to initiate the cascade. Upon stimulation of the teat, sensory neurons transmit a signal to the brain/hypothalamus/posterior pituitary. The latter secretes oxytocin that is delivered to the myoepithelial cells, which surround the alveolus and have receptors for oxytocin. The myoepithelial cells contract and squeeze the milk which has been secreted from the alveolar cell into the alveolar lumina, into small ducts, from which it is transported into larger ducts, i.e. the delivery of milk to the neonate (Senger, 1999).

\section{Characteristics of Mastitis}

Mastitis is the inflammatory response of milk-secreting tissue to injury produced by physical force, chemicals introduced into the gland, or most commonly intramammary infection from bacteria and their toxins (Swartz, 2006). Mastitis is the most devastating disease affecting adult dairy cows, and the associated economic losses, an estimated \$2 billion annually in the United States (Hockett et al., 2005); continue to present a serious burden to producers. Sordillo et al. (1997) estimated that mastitis affects one-third (1.5 quarters) [sic] of every dairy cow.

Clinical mastitis can be characterized by decreased milk production and increased numbers of leukocytes in milk, altered milk composition, increased body temperature, and red, warm, and/or swollen mammary quarters (Hansen, 2004). The degree of 
inflammation is diagnosed visually or palpably, and subclinical infections are diagnosed by assessments of somatic cells and/or bacteria present in milk (Swartz, 2006). Direct microscopic somatic cell counts (DMSCC) provide the most accurate means of assessing the degree of inflammation, but this is a rather slow laboratory procedure. Somatic cell counts, which electronically provide a more rapid technique, still need to be tested in the laboratory. The California Mastitis Test allows for "cow-side" assessment and is the preferred method for dairymen (Keisler et al., 1992).

There are certain times in the lactation cycle when mammary gland defenses fail to operate properly and cows become more susceptible to mastitis. Staphylococcus aureus (gram positive bacteria) and Esherichia coli (gram negative bacteria) account for the majority of clinical mastitis in cattle, which occurs most frequently during early lactation (Bannerman et al., 2004). However, some of these infections originate during the non-lactating period and result in clinical mastitis during the first 30 to 60 days after calving. Moreover mastitis can reduce reproductive efficiency; as manifested by increased days to first service, days open, and services per conception (Barker et al., 1998). Cows with clinical mastitis between first artificial insemination (AI) and conception required an additional AI, which lengthened the breeding period and the number of days to conception (Barker et al., 1998). Intramammary injection of an endotoxin to mimic a clinical mastitis infection induced luteolysis and influenced conception and early embryonic survival presumably by the release of inflammatory mediators (Schrick et al., 2001) and could stimulate production of prostaglandin F2- $\alpha$, which subsequently would cause luteal regression. 


\section{Peptidoglycan-Polysaccharide Complex Characteristics}

Wang et al. (2000) concluded that gram positive and gram negative bacteria have similar manifestations such as inflammation, fever, leukocytosis, hypotension, decreased peripheral perfusion, malaise, decreased appetite, sleepiness, and arthritis. The common cell wall component of both gram positive and gram negative bacteria is peptidoglycan also known as glycopeptide, mucopeptide or murein (Holaskova et al., 2004). As cited by Rosenthal (1994), peptidoglycan is a thick rigid layer composed of an overlapping lattice of two sugars, N-acetyl glucosamine (NAG) and N-acetyl muramic acid (NAM), that are crosslinked by amino acid bridges, generally the same four amino acids- Lalanine, D-alanine, D-glutamic acid, and diamino pimelic acid (DPA). The degree of cross-linking determines the degree of rigidity. In gram positive bacteria, peptidoglycan is a heavily cross-linked woven structure that wraps around the cell with its thickness in the range of $20-80 \mathrm{~mm}$; the form of which determines the organism's shape (bacilli, cocci, or spirilla). The thick peptidoglycan layer in gram positive bacteria is sensitive to the action of lysozyme and penicillin, which is often the antibiotic of choice for infections caused by gram positive organisms (Rosenthal, 1994). Lysozyme, a principle protein of phagocytes, is an enzyme that degrades the polysaccharide protective coating on the surface of many bacteria and viruses (glycoprotein) to allow other enzymes and antibodies to bind at specific attachment sites. Lysozyme is ubiquitous in infected tissue and by lysing peptidoglycan makes bacteria susceptible to osmotic and mechanical stressors (Ganz et al, 2003).

Peptidoglycan administered as an intoxicant elicited similar results as whole bacterium (Stewart et al., 2003; Holaskova et al., 2004). Peptidoglycan, has biological actions similar to endotoxin, the cell wall component of gram negative bacteria. Rotta 
(1975) reported that peptidoglycan, like endotoxin, causes pyrogenic responses in rabbits which can be eliminated by administering antiserum to peptidoglycan in a dosedependant manner. Dziarski (1979) found peptidoglycan to be a potent B-cell mitogen in mice; mitogens and polyclonal B cell activators stimulated lymphocytes in a nonspecific manner i.e. without participation of antigen-specific receptors (the variable part of immunoglobulin in the case of B lymphocytes). Besides its pyrogenic and mitogenic characteristics, Holaskova et al. (2004) cited that peptidoglycan is a main immunogenic component of gram positive bacteria wherein it activates macrophages and the complement pathway. Briefly, the complement pathway is made up of a large number of distinct plasma proteins that react with one another to opsonize pathogens and induce a series of inflammatory responses that help to fight infection. The complement system is activated through a triggered enzyme cascade and results in the opsonization of pathogens, recruitment of inflammatory cells, and direct killing of pathogens (Janeway, 2001).

\section{Innate Immune System and the Toll-like Receptor Pathway}

The innate immune system represents the first line of defense of the host to infection and is poised to recognize and respond to the earliest stage of infection. The innate immune system responds within 0 to 4 hours once bacterial pathogens enter the host to recognize and remove infectious agents by using preformed nonspecific effectors: antimicrobial proteins, peptides, phagocytes, natural killer cells, activated macrophages, cytokines and complement (Janeway, 2001). "The inherent capability of the innate immune system to respond to a large number of pathogens is mediated by its ability to recognize highly conserved motifs shared by diverse pathogens" (Bannerman et al., 
2004). Motifs referred to as pathogen-associated molecular patterns (PAMPs) include bacterial cell wall components, i.e. peptidoglycan. The PAMPs are composed of polysaccharides and polynucleotides that differ little from one pathogen to another but are not found in the host. Macrophages and neutrophils recognize pathogens by means of cell surface receptors that discriminate between PAMPs of various pathogens and self. The innate immune system senses invading pathogens by germ-line encoded pattern recognition receptors (PRRs, Takeuchi et al., 2001). Pattern recognition receptors and their corresponding PAMPS are evolutionarily conserved (Bannerman et al., 2004).

Pattern recognition receptors have three groups: secreted molecules that circulate in the blood and lymph, surface receptors on phagocytic cells, like macrophages, that bind the pathogen for engulfment, and cell-surface receptors that bind the pathogen, initiating a signal leading to the release of effector molecules, i.e. cytokines. Toll-like receptors (TLRs), an example of cell surface receptors, are present on the outside of macrophages, dendritic cells, and epithelial cells, to name a few. Those receptors identify the nature of the pathogen and turn on an effector response appropriate for signaling cascades that lead to the transcription of various cytokine genes (Ozinsky, 2000; Pioli et al., 2004; Supajatura et al., 2001; Takeuchi et al., 2001; Underhill et al., 1999). Toll-like receptors are type one transmembrane receptors characterized by the presence of extracellular leucine-rich repeat motifs and a cytoplasmic Toll/IL-1R (TIR) homology domain, which is required for the signaling that leads to the activation of a transcription factor, nuclear factor (NF)-אB (Takeuchi et al., 2001). In Medzhitov's and Janeway's (2000) immunological review, they stated that, in human beings, TLRs result in recruitment of an adapter protein (AP), MyD88 that binds to the cytoplasmic TIR 
domain, which then recruits interleukin (IL)-1 receptor-associated kinase (IRAK), a serine/threonine protein kinase. Once the MyD88 and IRAK receptor complex is formed, IRAK is autophosphorylated and then disassociates from MyD88. MyD88 associates with another AP, TNF receptor-associated factor 6 (TRAF6), which activates several members of mitogen activated protein kinase kinase kinase (MAP3K) family, namely NF-kB. Once NF-kB is activated, it translocates to the nucleus of the cell and transcribes of inflammatory cytokines.

Of the 10 cloned mammalian TLRs, TLR2 and TLR4 are the best characterized with respect to innate responses to bacteria (Pioli et al., 2004). A broader range of microbial products activate immune responses through engagement of TLR2 and TLR6, including peptidoglycan from gram-positive bacteria, bacterial lipopeptide, mycobacterium, and zymosan, a yeast cell wall particle (Pioli et al., 2004; Supajatura et al., 2001; Takeuchi et al., 2001; Underhill et al., 1999). Together, TLR2 and TLR6 coordinate macrophage activation by gram positive bacteria, peptidoglycan, and zymosan (Ozinsky, 2000). Toll-like receptor 2 needs a partner molecule to activate TNF- $\alpha$ production in macrophages (Ozinsky, 2000). It can form functional pairs with TLR6 or TLR1, and this interaction induces to cytokines (Ozinsky, 2000). In their study, Takeuchi et al. (2001) used TLR2 -/- and TLR6 -/- mice to demonstrate that TLR2 and TLR6 are both needed to activate NF-kB during infection with mycoplasmal macrophage-activating lipopeptide-2kD (MALP-2), a bacterial lipoprotein.

The main targets of peptidoglycan are monocytes and macrophages which are activated by two pattern recognition receptors: CD14 and Toll-like receptors (Wang et al., 2000). Given the microbial diversity of the female reproductive tract, Pioli et al. 
(2004) investigated the role that TLRs play in mediating innate immune recognition in the fallopian tubes, uterus, cervix, and ectocervix. Expression of TLR2 was higher in the cervix and fallopian tubes than in the uterus or ectocervix in human beings. Pioli et al. (2004) further stated that TLR2 expression, while constitutively low, can be induced post infection and that TLR2 expression can be augmented by TNF- $\alpha$. They proposed that TLR2 expression may be up-regulated in response to pathogenic challenge as a defense mechanism to protect the fetus from infection during pregnancy and labor.

\section{Cytokines and Acute Phase Proteins}

The main proinflammatory mediators induced by bacteria and their cell wall components are cytokines, primarily TNF- $\alpha$, IL-1, and IL-6 (Wang et al., 2000). During inflammatory responses (characterized by pain, redness, heat and swelling, at the site of infection) blood flow is increased due to an increase in vascular diameter. Endothelial cells lining blood vessels are activated to express adhesion molecules that promote binding of circulating leukocytes, and endothelial cells become separated leading to the exit of fluid and proteins, which cause edema. These changes are mediated by cytokines, which generally act over small distances, in short time spans, and at very low concentrations unless stimulated (Janeway, 2001). Cytokines are of particular importance in mediating communications between the conceptus and maternal cells, particularly the uterine epithelium and infiltrating leukocytes, both prior to implantation and as the placenta develops (Robertson et al., 1994).

A potent activator of endothelial cells (Janeway, 2001), TNF- $\alpha$ is a nonglycosylated protein with a molecular weight of $17 \mathrm{kDa}$ (Okuda et al., 2003). First described as a tumoricidal factor produced by activated macrophages, TNF- $\alpha$, has 
biological actions including proinflammatory mediator, cell differentiation control, renewal and reconstruction of tissue. It belongs to the TNF superfamily of 18 members, which have conserved $\mathrm{C}$ domains in common; this trimeric domain is responsible for receptor binding and has 20-30\% sequence homology with the rest of the family (Okuda et al., 2003). Arslan et al. (2004) showed increased levels of TNF- $\alpha$ concentrations in serum in 14 of 20 women who were pregnant less than 20 gestational weeks and had a past history of recurrent abortion and in 6 of 20 nonpregnant women with a past history of habitual abortion, compared to 2 of 20 healthy, nonpregnant women. The TNF- $\alpha$ could cause an increase in the synthesis of prostaglandins, hence uterine contractions, and have an important role in apoptosis, affect the implantation of embryos, and decrease blood flow to the embryo by causing thrombosis (development of clot in vein or artery) in the vessels.

The inflammatory effects of TNF- $\alpha$, IL- 1 and IL-6 initiate the acute phase response. For a general definition; the acute-phase of the inflammatory response refers to the wide-ranging physiological changes that are initiated immediately after an infection or physical trauma has occurred. "The mammalian acute phase response (APR) is characterized by fever, changes in vascular permeability; along with changes in the biosynthetic, metabolic and catabolic profiles of organs; the response is initiated and coordinated by a large number of diverse inflammatory mediators which include cytokines, anaphylatoxins, and glucocorticoids" (Paape M.J., et al., 2002). Cytokine's actions on hepatocytes in the acute-phase response involve a shift in protein synthesis, acute-phase proteins (APP), which are secreted by the liver into the blood plasma in response to cytokines released by macrophages in the presence of bacteria (Janeway, 
2001). The APP are of particular interest because they mimic the actions of antibodies. However, unlike antibodies, these proteins have a broad range or specificity for PAMPs and depend on cytokines for production.

One of the APP, serum amyloid A (SAA) in humans can exhibit dramatic increases in serum concentrations in response to inflammatory stimuli, and thus has been used as an inflammatory biomarker (Sasaki et al., 2003). Sasaki et al. (2003) stated that there is a high degree of conservation of SAA genes and proteins that have been maintained through evolution of eutherian mammals, which provides further evidence that they are likely to have important biological functions. Plasma haptoglobin (HP) and SAA are the two major biomarkers of the acute phase response to immune stress in cattle (Kahl and Elsasser 2005). Vogels et al. (1993) cited that acute-phase proteins, which are synthesized by the liver during a variety of acute inflammatory processes, may operate as oxygen radical scavengers, protease inhibitors, coagulation factors, and opsonins, and may therefore play a role in the nonspecific defense of the host to infection. Van der Meer et al. (1988) showed that a single dose of IL-1 administered at 24 hours, but not 6 or 0.5 hours, before a lethal gram negative bacterial infection enhanced survival due to the increased production of acute-phase proteins, which appear to balance or curtail the potential adverse consequences of the inflammatory process and restore homeostasis. Vogels et al. (1993) showed that D-galactosamine (GALN), a liver specific blocker of RNA and protein synthesis which acts by depleting UTP and thereby is able to block protein synthesis in the acute phase of infection, completely blocked IL-1-induced synthesis of acute-phase proteins. 


\section{Immunology of Maternal-fetal Interface}

Numerous investigators have used $\mathrm{CBA} / \mathrm{J}$ females mated with $\mathrm{DBA} / 2$ males (CBA/J X DBA/2), which spontaneously resorb $20-30 \%$ of litter, to examine the role of the immune system during mammalian pregnancy (Duclos et al., 1995; Chaouat G. et al., 1990; Gendron et al., 1990; Baines et al, 1996, 1997). Duclos et al. (1995) demonstrated that after the mating of $\mathrm{CBA} / \mathrm{J} \mathrm{X} \mathrm{DBA} / 2$ the majority (69.4\%) of embryos, representing embryos that are not spontaneously resorbed during pregnancy, expressed low amounts of the macrophage-specific marker, $\mathrm{F} 4 / 80^{+}$. However after the mating of $\mathrm{CBA} / \mathrm{J} \mathrm{X}$ $\mathrm{DBA} / 2,30.6 \%$ of embryos, representing the $20-30 \%$ of embryos that are spontaneously resorbed, expressed much higher amounts of $\mathrm{F} 4 / 80^{+}$, confirming the presence of macrophages at the feto-placental interface of resorbing embryos. Moreover, Duclos et al. (1995) stated that TNF- $\alpha$ could be involved in a positive feedback loop and recruit effector cells to the site of fetal distress. "The maternal response responsible for embryo loss primarily depends on the activation of the maternal innate immune system (natural killer (NK cells), activated macrophages, neutrophils) as opposed to the specific maternal acquired immune response mediated by helper $\mathrm{T}$ cells (Th1 and Th2), cytolytic T cells, and antibodies (Baines et al., 1997).

In human beings, leukocytes account for roughly $10 \%$ of stromal cells in the proliferative phase, $20 \%$ in the secretory phase, and $30 \%$ of endometrial stromal cells in early pregnancy (deciduas) (Dosiou and Giudice, 2004). The largest population in the endometrium consists of (NK) cells named large lymphocytes; which comprise over $70 \%$ of endometrial leukocytes ( $30 \%$ of stromal cells) during the first trimester. The increase of uterine $\mathrm{NK}(\mathrm{uNK})$ cells during pregnancy is due mainly to recruitment of uNK cell 
precursors from spleen, lymph nodes, and bone marrow and not from self renewal of existing uNK populations. Dosiou and Giudice (2004) further stated that human trophoblast cells are resistant to lysis by uNK cells, unless the latter have been stimulated by IL-2; however IL-2 is not present in the endometrium to any great extent during normal pregnancy. In their summary, they stated that uNK cells produce a variety of cytokines capable of directly influencing trophoblast growth and hormone production as well as implantation and vascularization of the decidua.

\section{Pregnancy Loss Due to Endotoxin and Peptidoglycan}

\section{A. Endotoxin-Induced Pregnancy Loss}

Animals show greater susceptibility to bacterial pathogens during pregnancy, and both endotoxin and peptidoglycan lysed from bacterial pathogens have lead to abortion and in the most severe cases, death of the dam (reviewed by Holaskova, 2002). Duclos et al. (1995) cited reports that modulation of innate resistance had observable effects on reproduction in contrast to the minimal effect of specific immune modulation, which strengthens the argument that the nonspecific (NK cells and macrophages) innate mechanisms may play a more important role in mammalian reproduction, at least early during pregnancy.

Macrophages initiate synthesis and release of massive amounts of TNF- $\alpha$ when activated by endotoxin/LPS (Hunt et al., 1996; Silver et al., 1994). Hunt et al. (1996) stated that TNF- $\alpha$ is thought to be an abhorrent molecule that should be avoided at all costs during pregnancy; administration of LPS or a large bolus of TNF- $\alpha$ to pregnant animals caused massive hemorrhage and pregnancy termination. TNF- $\alpha$ is produced by decidual explants in response to LPS (in vitro); high levels of TNF- $\alpha$ in human amniotic 
fluid are associated with infection and preterm labor. Placental and extra-placental membranes contain a large population of both macrophages and NK-like cells. Thus, Hunt et al. (1996) concluded that the high concentrations of TNF- $\alpha$ produced during chorioamnionitis and maternally transmitted bacterial diseases probably result from activation of those leukocytes, particularly the macrophages.

Silver et al. (1994) used an LPS-hyporesponsive murine strain $(\mathrm{C} 3 \mathrm{H} / \mathrm{HeJ})$ to establish whether LPS-induced death was due to a maternal or fetal response to LPS, and also investigated the involvement of TNF- $\alpha$ in fetal death caused by LPS. They concluded that LPS caused fetal loss via a maternal effect as opposed to a direct fetal effect, because there was no LPS-induced fetal loss in endotoxin-resistant mothers even when fetuses were genetically endotoxin-susceptible. Silver and coworkers speculated that [this] resistance to LPS-induced fetal death in $\mathrm{C} 3 \mathrm{H} / \mathrm{HeJ}$ mice [was] at least partially due to impaired TNF- $\alpha$ production/secretion in response to LPS intoxication. They speculated that TNF- $\alpha$-induced fetal death is via the elaboration of prostaglandins; eicosanoids are known abortifacients and are produced by gestational tissues in response to TNF- $\alpha$. Fetal death caused by LPS administration appears to be due to a maternal response as opposed to a direct fetal effect, therefore suppression of the maternal immune response, particularly the actions of TNF- $\alpha$, may improve fetal outcome in cases of maternal bacterial infection (Silver et al., 1994). Gendron et al. (1990) showed that concentrations of LPS-induced TNF- $\alpha$ were reduced by $90 \%$ after pretreatment with the TNF- $\alpha$ suppressing drug, pentoxifylline (PXF), in CBA/J X DBA/2 mice on Day 8 of gestation. Further, the effects of LPS appeared to be uterine-specific, as no other tissues showed any gross signs of pathology. 


\section{B. Peptidoglycan-Induced Pregnancy Loss}

Bacteria lysed in the host release peptidoglycan, which elicits an immune response that has been found to be detrimental to pregnancy (Stewart et al., 2003; Holaskova et al., 2004). Similarly to LPS, peptidoglycan-polysaccharide (PG-PS) induced production of prostaglandins and those factors, and not fever, increased cortisol, or decreased progesterone secretion, reduced pregnancy rates of treated versus control ewes (Stewart et al., 2003). Fortunato et al. (1998) showed that PG-PS induced expression of IL-6 and IL-8, and that LPS induced an even greater secretion of IL-6 and IL-8 in amniochorion membranes. They suggested that the cytokine profile differed based on the types of bacterial isolate, population size and the type of toxin/enzyme generated, which [might] help in designing strategies for understanding and controlling infection associated with preterm labor.

\section{VIIII.Embryotoxicity}

Baines et al. (1997) showed that early embryo loss is mediated by the in vivo triggering of primed decidual macrophages; the precise relationship between decidual NK (uNK) cells and macrophages is not fully understood. However, primed uNK cells can produce IFN- $\gamma$ which can activate macrophages capable of producing increased quantities of TNF- $\alpha$ and nitric oxide (NO) if triggered by exposure to LPS or TNF- $\alpha$. Although Baines et al. (1997) expected that embryos in the later stages of resorption would have large infiltrates of cells producing TNF- $\alpha$ and nitric oxide, approximately $20-30 \%$ of $\mathrm{CBA} / \mathrm{J} \mathrm{X} \mathrm{DBA} / 2 \mathrm{~F} 1$ embryos collected between 6 and 8 days of gestation showed increases in uNK cells and activated macrophage infiltrates expressing messages for inducible nitric oxide synthase (iNOS), TNF- $\alpha$, and IFN- $\gamma$. Haddad et al. (1997) stated 
that NO is a short-lived pleiotropic mediator that is synthesized from L-arginine by constitutive or inducible NOS; iNOS is inducible by IFN- $\gamma$, TNF- $\alpha$, IL-1, and LPS.

Previous work (Haddad et al., 1995) observed maternal macrophages at the implantation sites of $29 \%$ of embryos (day 12) produced significant amounts of nitrate and nitrite, the oxidation products of NO in response to LPS, and that embryo survival was dramatically enhanced in pregnant $\mathrm{CBA} / \mathrm{J}$ mice treated with an NOS inhibitor, aminoguanidine, indicating that NO was essential for embryonic loss in their model. Haddad et al. (1997) showed that as soon as day 8 of gestation $32 \%$ of embryos had increases of iNOS mRNA and $29 \%$ of embryos had increases of TNF- $\alpha$ mRNA, with no apparent pathology. These results provide evidence for the presence of activated macrophages at implantation sites before overt embryo damage occurs. TNF- $\alpha$ has been shown to be involved in fetal resorption; TNF- $\alpha$ is a multifunctional cytokine produced by a variety of cell types. Depending on stimulus and cellular target TNF- $\alpha$ has cytotoxic, cytostatic, immunomodualtory, growth promoting and many other activities (Haddad et al., 1997). They further stated that exogenous TNF- $\alpha$ could induce abortion and that inhibition of TNF- $\alpha$ production by anti-TNF- $\alpha$ or pentoxifylline increased embryo survival.

Pampfer et al. (1995) demonstrated that blocking the expression of TNF- $\alpha$ Rp60 (TNF receptor) protected rat blastocysts from TNF- $\alpha$. Further, average cell number detected in inner cell mass and trophblast lineages decreased after exposure to TNF- $\alpha$ in the presence of sense oligonucleotides to TNF- $\alpha$ Rp60, but the effect was fully prevented with the antisense version of the same oligonucleotide. Pampfer et al. (1995) suggested that the negative effect of TNF- $\alpha$ in rat blastocysts was mediated solely by TNF- $\alpha$ Rp60 and not second type of TNF- $\alpha$ receptor Rp80; the current consensus is that activation of 
TNF- $\alpha$ Rp60 alone is sufficient to trigger most of the biological activities of TNF- $\alpha$ and that TNF- $\alpha$ Rp80 acts only as an accessory component to TNF- $\alpha$ Rp60 to facilitate or amplify a small subset of effects.

Baines et al. (1996) reported that prior immunization with both paternal specific MHC and non-specific antigen LPS and complete Freund's adjuvant (CFA) decreased the frequency of spontaneous early embryo resorption in murine pregnancy. However, Baines et al. (1996) found that none of the immunotherapeutic vaccinations or matings had a permanent effect on CBA/J X DBA/2 embryo survival, which is what one would expect if specific immune mediators were involved. It was speculated that CFA had a role in decreasing the frequency of spontaneous resorption in CBA/J X DBA/2 mice. However, the embryo enhancing effect of prior immunization with CFA was limited to a few weeks; similarly, LPS immunization protected embryos from LPS-induced early embryonic abortion, but was short lived (Baines et al., 1996).

Effects of TNF- $\alpha$ have not been characterized using PG-PS. Stewart et al. (2003) showed an increase in PGFM from controls upon administration of PG-PS in day-5 pregnant ewes at 15, 30 and $60 \mathrm{ug} / \mathrm{kg}$ BW dosages. Additionally, Stewart et al. (2003) noticed decreases in progesterone during this time. This is in accordance with Costine et al. (2001) who showed that early regressing corpora lutea had embryotoxic effects despite progestogen supplementation in ewes. Chronic treatment of ewes with exogenous PGF2- $\alpha$ reduced embryonic survival despite progestogen replacement therapy and ewes that were lutectomized had higher pregnancy rates than ewes that were sham lutectomized. Holaskova et al. (2004) showed that immunization with PG-PS in ewe lambs had cumulative effects decreasing pregnancy rate with increased exposure to PG- 
PS. It has been suggested through the work of Stewart et al. (2003) and Holaskova et al. (2004) that the early embryonic loss in the PG-PS intoxicated ewe model works through the same direct and indirect mechanisms as in the LPS-induced early embryonic loss models i.e. through increases in concentrations of PGF2 $\alpha$ and TNF- $\alpha$. Kahl and Elsasser (2005) cited several lines of evidence that the outcome of some infections may be aligned with, and perhaps predicted by, plasma concentrations of cytokines during disease, particularly tumor necrosis factor (TNF- $\alpha)$. Transient bursts of TNF- $\alpha$ production are essential for initiating critical mediator response cascades of other cytokines, arachidonic/eicosapentanoic acid compounds, acute phase response proteins, nitric oxide and adrenomedullin.

\section{Summary}

There are several homeostatic changes to consider after a systemic intoxication of PG-PS early (day 5) pregnant ewes. First, after PG-PS intoxication [into] the jugular vein, the bacterial cell wall component, PG-PS, enters systemic circulation. Once inside the host's circulation the individual bacteria, in this case the cell wall component PG-PS, homes to its predetermined preferential location. This is a unique characteristic of the bacterium and its components.

Second, during PG-PS intoxication, various augmentations occur to the hypothalamic-pituitary-gonadal axis and hypothalamic-pituitary-adrenal axis. Stewart et al. (2003) have shown that in response to the PG-PS intoxication, cortisol, secreted from the adrenals, increases via a biphasic response. Stewart et al. (2003) cited that cortisol had been shown to decrease release of pyrogenic substances from leukocytes and suggested that increased releases of cortisol in response to fever controlled the pyretic 
response. However, pregnancy loss was not a function of fever or cortisol per se, because ewes treated with low dosages of PG-PS maintained pregnancy. Stewart et al. (2003) also found that estrogen did not increase after PG-PS dosage, but that progesterone [levels did] decreased in all treated ewes. Further, Stewart et al. (2003) saw increases in PGFM in all treated ewes. It was speculated that pregnancy loss was not a result of increased cortisol, fever, or decreased progesterone due to the fact that ewes in the low PG-PS dose group maintained pregnancy despite the low concentrations of progesterone; but that PGFM, and a potential inflammatory mediator could be contributing to embryonic loss (Stewart et al., 2003).

Third, it is important to consider how the innate immune system works during the acute-phase response (APR). Once PG-PS enters the host, the innate immune system quickly recruits cellular mediators to the site of the infection. In the case were PG-PS enters the blood stream directly, PG-PS is transported to all tissues and local and systemic innate immune responses occur in tissues that have toll-like receptors (TLR-2) for PG-PS. After recognition of the bacteria by the immune cells there is up-regulation of cytotoxic activity, phagocytosis, cytokine production, complement initiation, acute-phase protein production, and recruitment of immune cells. Cytokine production is particularly important to the local innate immune response, because it perpetuates the inflammatory response in the local tissues so that adaptive immunity can take over. Cytokine production, however, can easily get out of hand, and in response to a very large dosage of bacteria (lethal dosage), production of cytokines can be so high as to kill the host or cause severe tissue damage. This is not frequently the case, however, when one considers a pregnant animal, what is not lethal to the mother can be lethal to the embryo. 
Embryotoxicity induced by PG-PS [in] early pregnant ewes has not been described fully. Steps in identifying the specific characteristics of PG-PS-induced embryonic loss in sheep will be helpful in determining the appropriate stages at which to apply future therapies to prevent reproductive failure. 


\section{Statement of the Problem}

Pressure has been placed on the agricultural industry to maintain high yields of meat and dairy products on an annual basis. Agricultural researchers have been concerned with decreases in production from prolonged calving intervals due to early embryonic loss and have attempted to decipher causal factors for the loss. Occurrence of mastitis during early embryonic development has detrimental effects on maintenance of pregnancy and can result in either resorption or abortion of the embryo. Research has investigated associations of pathogens that cause mastitis in mediating that embryonic loss. Production of TNF- $\alpha$, nitric oxide and PGF2- $\alpha$ increase during early embryonic loss induced by intoxication with lipopolysaccharide (LPS), a cellular wall component of gram negative bacteria.

The primary objective of this study was to induce the protective mechanisms of the innate immune system by intoxicating day-5 pregnant ewes with PG-PS, a cellular wall component of gram negative and gram positive bacteria, and to evaluate that induction by measuring concentrations of TNF- $\alpha$, a pivotal inflammatory cytokine, in venous blood both locally, from the reproductive tract, and in systemic circulation. The experimental null hypothesis was that PG-PS intoxication would not result in changes in concentrations of TNF- $\alpha$ in either the jugular or [posterior vena cava]. The secondary objective was to profile the production of an acute phase protein, serum amyloid A (SAA), during PG-PS intoxication in day-5 pregnant ewes. The associated experimental null hypothesis was that concentrations of SAA would not differ between treated and control ewes. 


\section{Methods and Materials}

\section{Synchronization Protocol for Ewes:}

Twenty-four Suffolk ewes (average body weight $81.2 \mathrm{~kg}$ ) from the WVU farm were used [in] a protocol approved by the WVU Institutional Animal Care and Use Committee. Ewes were subjected to a protocol for synchronization of estrus (Inskeep et al., 1983) before treatment. Briefly, a vasectomized ram with marking harness was placed into a pen with a maximum of 12 ewes for three days. On the third day, unmarked ewes were injected (i.m.) twice with $1 \mathrm{~mL}(5 \mathrm{mg})$ of $\mathrm{PGF}_{2} \alpha$ (Lutalyse ${ }^{\circledR}$, UpJohnPharmacia, Kalamazoo, MI) three hours apart. After the second injection of $\mathrm{PGF}_{2} \alpha$, an intact ram with a marking harness was placed into the pen with the ewes. Observation for estrus was conducted at 12 hour intervals up to 36 hours post-injection. A second replicate of 12 ewes were observed for estrus. Estrual ewes were mated at least twice with the first mating termed day 0 of gestation. In replicate 1 (September 27- October 3, 2005), five of the seven estrual ewes were selected randomly to be placed on experiment. In replicate 2 (October 4 - October 10, 2005), five of six estrual ewes were selected randomly to be placed on experiment.

\section{Catheter Construction and Placement (Day 4 of gestation) \\ a) Catheter Construction The catheters were constructed from polyvinyl} tubing that was measured to $80 \mathrm{~cm}$ in length and marked at 48,50 , and $52 \mathrm{~cm}$ with a permanent marker. An 18 gauge needle was filed off to be inserted into the collecting end of the catheter. Additionally, a filed off $1 \mathrm{~mL}$ syringe casing was inserted at the end of the needle to plug the collecting end between collections. 
b) Catheter Placement A catheter was placed into the caudal vena cava via the lateral saphenous vein, the caudal femoral vein and the external iliac. Another catheter, I-CATH Intravenous Placement Unit with Stylet ${ }^{\circledR}$ (CharterMed Inc., Lakewood, NJ), was used to catheterize the jugular vein. On the evening of day 4 , ewes were prepared for catheterization via clipping wool from the neck and hock areas and cleaning those areas with Betadine ${ }^{\circledR}$ (The Purdue-Frederick Company, Stamford, CT) solution. Ewes were [sedated] ( $0.3 \mathrm{mg} / \mathrm{kg} \mathrm{BW}$, i.v.) with Diazepam ${ }^{\circledR}$ (Hoffmann-La Roche Inc., Nutley, NJ) for muscle relaxation during vena caval catheter placement, additional [sedation] was given as needed. Also, the area around the saphenous vein was locally anesthetized, with 3 to $5 \mathrm{~mL}$ Lidocaine $^{\circledR}$ (Butler Company, Columbus, OH). Aseptic procedures were followed for catheter placements; surgical instruments and saphenous vein catheters were soaked in Novalsan solution prior to placement.

The saphenous vein was isolated easily by blunt dissection as described by Benoit, and Dailey (1991). The saphenous vein was located approximately $3 \mathrm{~cm}$ lateral to the Achilles tendon, and could be seen through a layer of fascia after the skin was incised using sterile surgical blades ${ }^{\circledR}$ (Propper Manufacturing Co., Inc., Long Island City, NY). Once the saphenous vein was isolated, a 16 gauge needle was used to puncture the vein and a catheter introducer ${ }^{\circledR}$ (Becton Dickinson and Company, Franklin Lakes, NJ) was utilized to allow for guidance of the pre-measured catheter into the vena cava via the saphenous vein.

Blood samples were taken with heparinized tubes at 48,50 , and $52 \mathrm{~cm}$, and catheters were pulled back and secured with internal suture at $50 \mathrm{~cm}$ and capped. Briefly, heparinzed tubes for the experiment were made using 250 Units of Heparin ${ }^{\circledR}$ (Sigma, 
Atlanta, GA)/ $\mathrm{mL}$ of $9 \% \mathrm{NaCl}$ solution. Diluted heparin $(5 \mathrm{~mL})$ was vortexed inside tubes to coat the walls of the tubes and then residual heparin solution was discarded. After blood collection special care was taken to secure the catheters to the neck and leg loosely with medical tape and $\operatorname{VetWrap}^{\circledR}(3 \mathrm{M}$, St. Paul, MN). Each ewe was placed in a lambing crate individually to prevent ewes from removing the catheters. On the morning of day 5 , ewes were removed from the individual lambing crates and assigned randomly into one of two larger pens. Then the ewes were assigned randomly to one of two treatment groups within each pen, so that each pen had at least one treated and one control ewe.

\section{PG-PS/ NaCL Preparation, Assignment of Treatments, and Blood Collection (Day 5 of gestation)}

a) $\quad P G-P S / N a C L$ Preparation Twenty milligrams $(6.6 \mathrm{mg} / \mathrm{mL})$ of $100 \mathrm{P}$ PG-PS were purchased (BD Lee Laboratories, Grayson, GA). Following BD Lee Laboratories protocol for rats, the PG-PS was diluted with $0.9 \% \mathrm{NaCL}$ solution to a concentration of $0.450 \mathrm{mg} / \mathrm{mL}$, prior to administering dosages. Dosages of $30 \mathrm{ug} / \mathrm{kg}$ BW were given following the protocol of Stewart et al. (2003). A total of $5.4 \mathrm{~mL}$ of diluted PG-PS was given to each treated ewe $(\mathrm{n}=6)$ and a total of $5.4 \mathrm{~mL}$ of $0.9 \% \mathrm{NaCL}$ solution was given to each control ewe $(n=4)$ as the sham inoculation.

c) Blood Collection Heparinized tubes were made as previously described and stored. Two sets of tubes were labeled: one set for the jugular vein collections and the second set for the saphenous vein collections. Collection of blood into $5 \mathrm{~mL}$ syringes began at 10 am on October 8 (Week 1) and 8 am on October 15, 2006 (Week 2). The first collection, roughly $5 \mathrm{~mL}$ of blood from each catheter, was made before intoxications to establish baseline. Collections were placed into appropriate heparinized tubes and 
inverted with Parafilm ${ }^{\circledR}$ (American National Can Greenwich, CT) and stored in an ice chest. Intoxications were given immediately collections after baseline via the jugular vein. Then, blood was collected every 15 minutes for 6 hours. Blood was stored on ice until it was centrifuged and aliquots were stored at $-20^{\circ} \mathrm{C}$.

\section{Assays}

Concentrations of progesterone [levels] in vena caval samples were assayed using Coat-A-Count kit ${ }^{\circledR}$ purchased from (Diagnostic Products Corporation, Los Angeles, CA). Procedures outlined by the manufacturer (100 uL of sample/tube); were followed and concentrations of progesterone were read using WALLAC 1470 WIZARD Automatic Gamma Counter ${ }^{\circledR}$ (Wallac Inc., Gaithersburg, MD). The progesterone assay's sensitivity was $0.29 \mathrm{ng} / \mathrm{mL}$ and the intra-assay coefficient of variation for the quality controls averaged $7.5 \%$ (Table 1). Figure 1 shows that concentrations of progesterone did not differ with catheter lengths of 48 to $52 \mathrm{~cm}$, so catheters were placed at $50 \mathrm{~cm}$.

The cytokine, TNF- $\alpha$, also known as cachectin, is secreted by macrophages in response to various pathogens. TNF- $\alpha$ was assayed in both the jugular samples and the [vena caval] samples in single assays at the USDA in Beltsville, Maryland under the supervision of Dr. Ted Elsasser in the Growth Biology Laboratory, following, the protocol of Kenison et al. (1990) non-equilibrium assay. The intra-assay coefficient of variation for the quality controls is represented in Table 1.

Serum amyloid protein A (SAA) is a putative serum precursor of the amyloid A protein. It is well documented that SAA is a biomarker for infection (Nakayama T. et al., 1993). A multispecies SAA solid phase ELISA kit was purchased from Biosource International, Inc., Camarillo, CA. Outlined procedures from Biosource International, 
Inc. were followed accordingly except that samples were diluted 1:8000, instead of 1:500 as recommended by manufacturer; based on assays; ELISA plates were read using SPECTRAmax ${ }^{\circledR}$ PLUS $^{384}$ (Molecular Devices Corporation, Sunnyvale CA). The data were transformed by subtracting all values at time points 15 minutes through 2 hours from baseline and then by multiplying each value by 100 to express the data as percent change from baseline.

Table 1 Assay Coefficients of Variation

\begin{tabular}{|l|l|l|}
\hline Variable Measured & Item & CV\% \\
\hline Progesterone & OVX & 16.22 \\
\hline & OVX-S & 6.15 \\
\hline & SB & 3.47 \\
\hline & SS & 4.42 \\
\hline TNF- $\alpha$ & LC & 7.20 \\
\hline & BO (Jugular) & Average $=7.49$ \\
\hline & BO(Vena Caval) & 0.2196 \\
\hline & & \\
\hline
\end{tabular}


Figure 1 Day 4 of Gestation Progesterone Profiles of Vena Caval Catheters

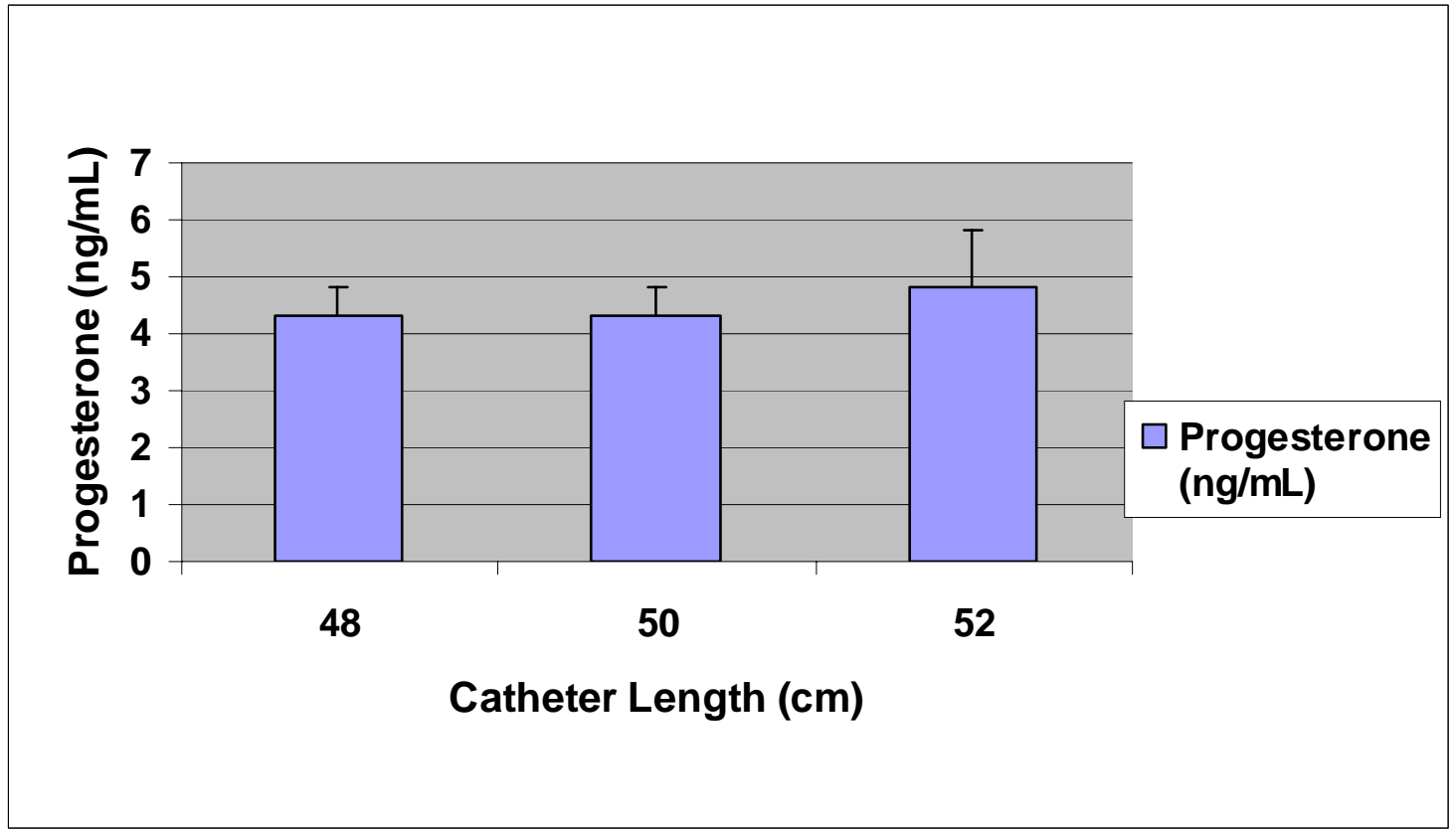

\section{Statistics}

The primary experimental null hypothesis was:

1. Peptidoglycan-polysaccharide intoxications do not result in a difference of concentrations in TNF- $\alpha$ between the jugular and vena cava.

The secondary experimental null hypothesis was:

2. Concentrations of Serum Amyloid A are not different between control and treated ewes.

The results were analyzed using repeated measures analysis of variance SAS GLM procedure (1999, SAS Institute, Carry, NC). Significance level was 0.05. 


\section{Results}

\section{TNF- $\alpha$ concentrations in Suffolk Ewes:}

Treatment of Suffolk ewes with 30ug/kg BW PG-PS complex (PG-PS, n=6) increased $(p=0.0021)$ production of TNF- $\alpha$ measured in the vena cava compared to control ewes (Figure 2, $n=4$ ). However, concentration of TNF- $\alpha$ production in the jugular vein after PG-PS intoxication was not significantly different $(\mathrm{p}>0.05)$ in treated compared to control ewes. Concentrations of TNF- $\alpha$ from treated and control ewes did not differ with site of sampling [p $>0.05$, Figure $3, n=4]$.

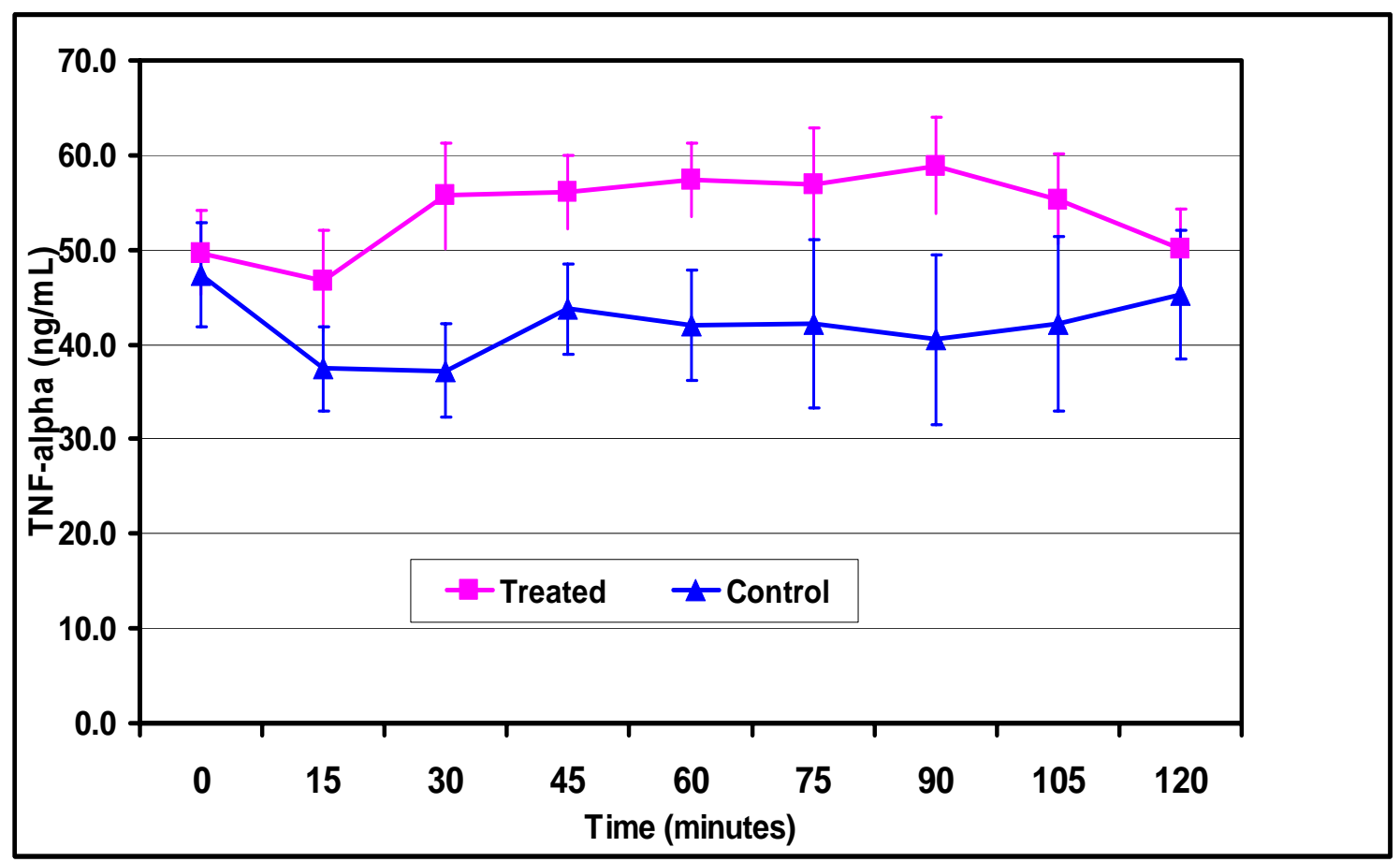

Figure 2 Vena Caval Concentrations of TNF-a 


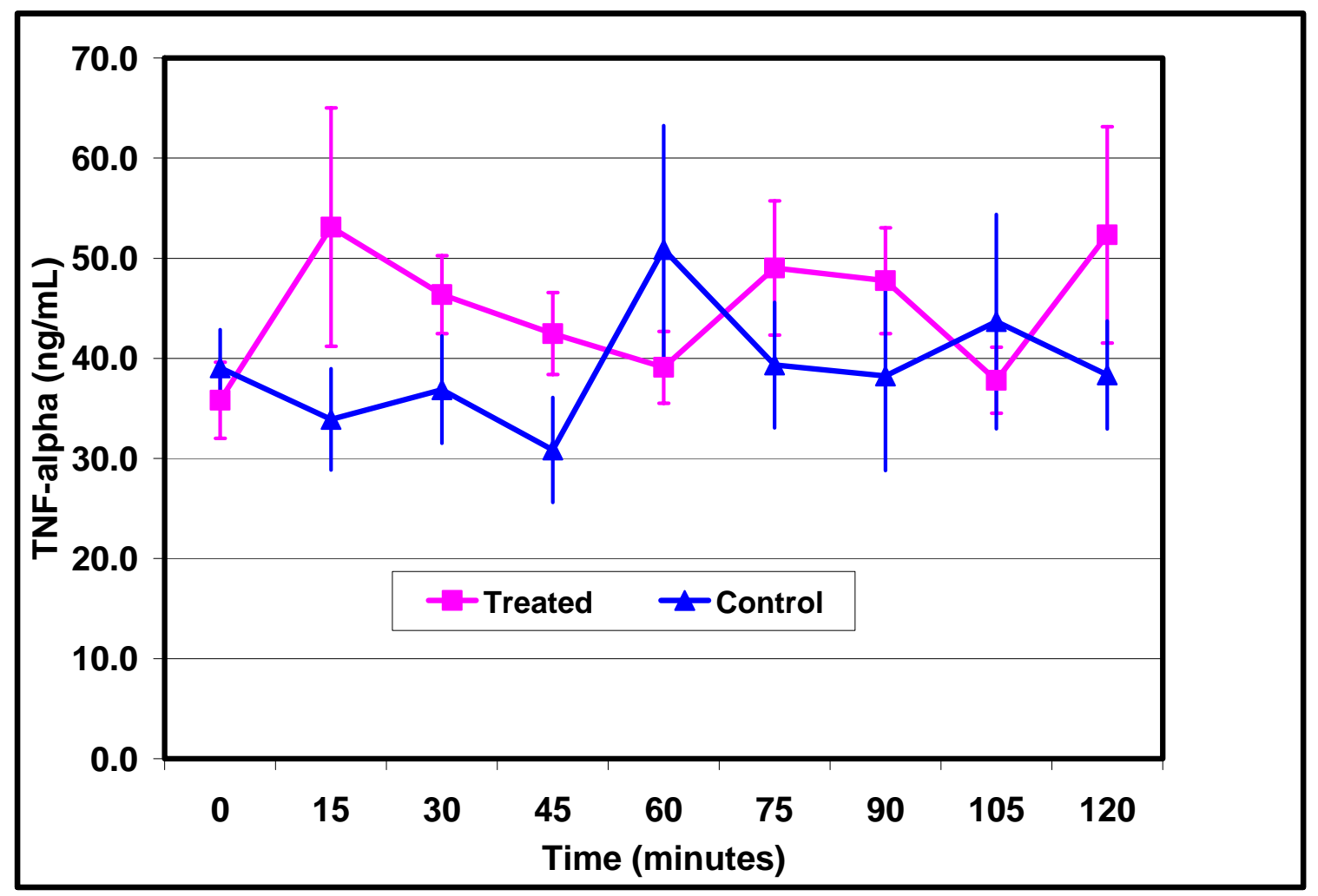

Figure 3 Jugular Concentrations of TNF- $\alpha$

II. Serum Amyloid A concentrations in Suffolk Ewes:

Treatment of Suffolk ewes with PG-PS did not affect concentrations of serum amyloid A ( $p>0.05)$. 


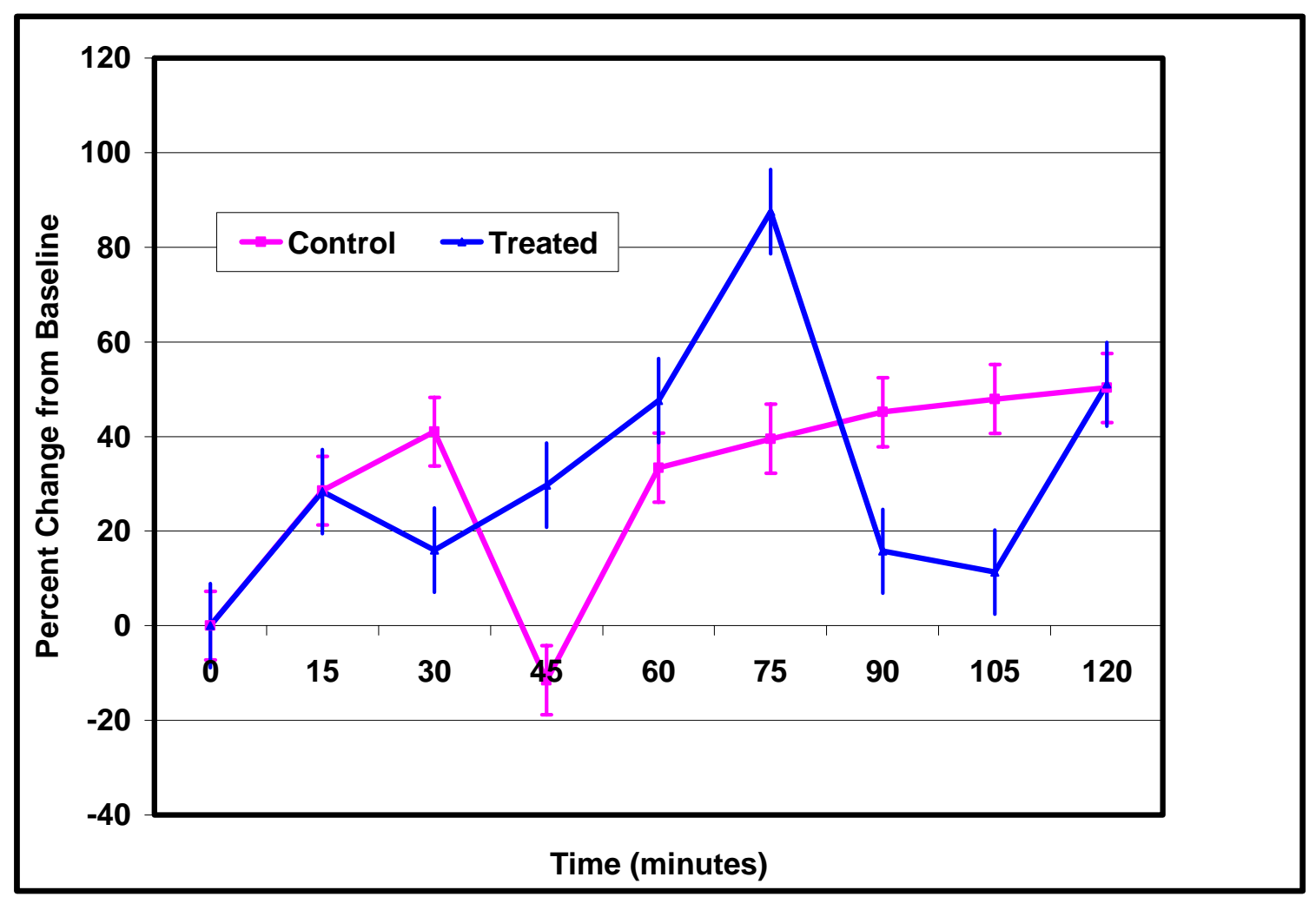

Figure 4 Jugular Concentrations of Serum Amyloid A 


\section{Discussion}

The $30 \mathrm{ug} / \mathrm{kg}$ BW PG-PS (medium dosage, Stewart et al. 2003) was sufficient to elicit a local immune response as quantified by increased concentrations of TNF- $\alpha$ in the [caudal vena cava] of treated ewes, but not enough to increase TNF- $\alpha$ in the jugular vein above controls, representing systemic circulation in treated ewes. Stewart et al. (2003) showed that a $30 \mathrm{ug} / \mathrm{kg} \mathrm{BW}$ dosage of PG-PS did not result in lowered pregnancy rates. Thus in the current study it can be said that, a $30 \mathrm{ug} / \mathrm{kg}$ BW PG-PS challenge was enough to illicit the production of TNF- $\alpha$ in proximity to the reproductive tract, but in accordance with Stewart et al. (2003), the dosage was not high enough to meet the threshold for embryonic toxicity, or to cause sepsis. Stewart et al. (2003) were among the first to observe that upon a PG-PS challenge in early pregnant ewes (day 5), prostaglandin (PGF2- $\alpha$ ) as measured by its metabolite, PGFM, subsequently increased in a dosedependant manner, and that progesterone declined in all treated ewes. However, Stewart et al. (2003) observed that pregnancy rates declined only in ewes treated with high dosages of PG-PS, in which PGFM was high, but that pregnancy rates were maintained in medium and low dosages of PG-PS in which PGFM was lower, arguing for another synergistic factor in the equation for embryonic loss. Costine et al. (2001) showed that exogenous PGF2- $\alpha$, and the regressing CL could be embryotoxic on days 4-7 after mating in progestagen-supplemented ewes. Holaskova et al. (2004) showed that immunization to PG-PS did not prevent pregnancy loss even though IgG anti-PG-PS titers were high. Therefore it was suggested that the innate immune system may have a more important role during early embryonic loss. As cited by Stewart et al. (2003), in vitro culture of preimplantation mouse embryos with TNF- $\alpha$ prevented embryos from 
reaching the blastocyst stage and decreased total cell number. Stewart et al. (2003) stated that increases in inflammatory cytokines, such as TNF- $\alpha$, could potentially have direct effects on embryonic survival after PG-PS treatment. Therefore the local production of TNF- $\alpha$ from the reproductive tract and in proximity to the reproductive tract would be considered important characteristics of the PG-PS intoxicated animal.

To further delineate what physiological impacts that resulted from the single 30 ug/kg BW PG-PS intoxication, SAA was measured. Serum amyloid A, as discussed in the literature review, is an acute phase protein. Plasma SAA can be increased up to 1000fold of the basal level in inflammatory disorders in human and other species, suggesting that it is an important indicator of disease status as cited in Sadaki K. et al. (2003). In the present study, concentrations of SAA were not significantly different in the PG-PS treated ewes from the controls. However no strong conclusions can be made about the current observation of SAA for the following reasons:

1) Species variability; a multispecies SAA solid phase ELISA kit was purchased from Biosource Inc., Camerillo, CA validated for bovine, porcine, canine, human, and equine. The purchased SAA assay kit was not validated for sheep. However, based on the premise of a high degree of conservation of the SAA genes and proteins that have been maintained through evolution of eutherian animals, SAA and other acute-phase proteins are likely to have important biological actions similarly seen in multiple species; (Sasaki K. et al. 2003) and should not be variable. 
2) Sampling; as previously mentioned serum amyloid A (SAA) is produced after initiation of the acute phase response to inflammation. Cytokines such as IL-1, IL-2 and TNF- $\alpha$ induce acute-phase protein production and secretion from liver hepatocytes. Thus, there is an important lag time to consider when sampling the intoxicated animal. This was not considered in the current study; therefore blood sampling could be taken at later times to improve the likelihood of observing significant differences in treated vs. control ewes.

3) Concentrations of SAA and accessory proteins in sheep plasma; in a preliminary assay it was determined that sheep plasma samples were too concentrated with SAA as compared to standards. A 1:8000 dilution was determined optimum; however when samples were run again, neither control or treated blood samples started at the same baseline. There is a potential that an accessory protein is interfering with the assay for SAA in treated ewes. Perhaps further dilution and validation would have been appropriate.

It is well known that during early pregnancy immune cellular infiltration of decidual tissue is up-regulated. An "inflammatory" response to semen occurs on the day of mating and is characterized by massive inflammatory leukocyte infiltration and heightened cytokine gene expression in the uterus as cited by Dalton et al. (1994). This depicts an ironic situation wherein after opsonizing bacterial pathogens are introduced to the reproductive tract of the dam at mating, the immune system switches its focus to downplay its defense mechanisms for the duration of early pregnancy until maternal 
recognition, implantation, and establishment of pregnancy occur. No doubt progesterone plays a large role in the "switch" of the immune system; progesterone has been described as an immuno-inhibitory hormone whose actions down-regulate proinflammatory immune activities. It has been documented by Seals et al. (2002) that progesterone treatments administered twice daily to both ovariectomized and intact postpartum ewes before intrauterine inoculation with bacteria resulted in suppressed uterine immunity therefore leaving the uterus susceptible to bacterial induced infections. Seals et al. (2002) suggested that the uterine immune system is up-regulated postpartum until it is exposed to progesterone which allows the uterine immune system to become down-regulated and susceptible to infections. In the current study, catheter placement in the vena cava showed concentrations of progesterone appropriate for day-5 pregnant ewes. During early pregnancy concentrations of progesterone are derived from the (CL), until the placenta takes over, around day 50, in ewes production of progesterone needed for maintenance of pregnancy. The CL itself is a transient endocrine organ that produces progesterone needed to keep the uterine endometrium rich with glandular secretions ideal for attachment/implantation of the embryo. The maintenance of the CL is critical, and can be susceptible to various insults, most specifically those induced after inflammation i.e. PGF2- $\alpha$, acute phase proteins and TNF- $\alpha$ production.

LPS challenges have been shown to activate macrophages along with NK cells, which work in synergy to produce large amounts of TNF- $\alpha$ local to the embryo during early pregnancy in CBA/J X DBA/2 mice (Duclos et al., 1995; Chaouat et al., 1990; Gendron et al., 1990; Baines et al., 1996, 1997). Further, LPS-induced embryonic death results from maternal and not fetal factors as shown in LPS-hyporesponsive murine strain 
$\mathrm{C} 3 \mathrm{H} / \mathrm{HeJ}$ (Silver et al., 1994). The current research observations show local, maternal (in proximity to reproductive tract) TNF- $\alpha$ production in response to PG-PS treatment during this time (day 5) of early pregnancy in ewes. Attempts to further classify the mechanisms of a PG-PS intoxication by measuring SAA profiles were not successful in this current study, however further research is needed to characterize the innate immune systems effects early embryonic loss in all species induced by PG-PS intoxication and infection.

It is important not to over look, whether in cattle or sheep, that proper management techniques will help curb mastitis and the associated embryonic loss in high yielding dairy animals. Pyorala (2002) states that the best progress in the control of mastitis, short term, can be made by improving the nutrition, environment and management of dairy animals. However, in the long term, it will be critical for scientists to understand the host's innate and adaptive defense mechanisms associated with each individual pathogen of mastitis and its links to embryonic loss before clinical applications, promised by biotechnologies, will be of use to the producer. 


\section{References}

Akers, RM. 2000. Selection for Milk Production from a Lactation Biology Viewpoint. Journal of Dairy Science. 83: 1151-1158.

Arslan, E, M Colakoglu, C Celik, K Gezinc, A Acar, M Capar; M Akoz, C Akyurek. 2004. Serum TNF-alpha, IL-6, Lupus anticoagulant and anticardiolipin antibody in women with and without a past history of recurrent miscarriage. Archives of Gynecology and Obstetrics. 270: 227-229.

Baines, MG, AJ Duclos, AR DeFougerolles, RL Gendron. 1996. Immunological Prevention of Spontaneous Early Embryo Resorption is Mediated by NonSpecific Immunostimulation. American Journal of Reproductive Immunology. 35: 34-42.

Baines, MG, AJ Duclos, E Antecka, EK Haddad. 1997. Decidual Infiltration and Activation of Macrophages Leads to Early Embryo Loss. American Journal of Reproductive Immunology. 37: 471-477.

Bannerman, DD; MJ Paape; JW Lee; X Zhao, JC Hope, P Rainard. 2004. Escherichia Coli and Staphylococcus aureus Elicit Differential Innate Immune Responses Following Intramammary Infection. Clinical and Diagnostic Laboratory Immunology. 11: 463-472.

Barker, AR, FN Schrick, MJ Lewis, HH Dowlen, SP Oliver. 1998. Influence of Clinical Mastitis During Early Lactation on Reproductive Performance of Jersey Cows. Journal of Dairy Science. 81: 1285-1290.

Benoit, A, RA Dailey. 1991. Catheterization of the Caudal Vena Cava via the Lateral Saphenous Vein in the Ewe, Cow, Gilt: An Alternative to Utero-Ovarian and Medial Coccygeal Vein Catheters. Journal of Animal Science. 69: 2971-2979.

Biosource International, Inc. 2006. Technical Data Sheet. Multispecies SAA. Camarillo, California.

Blandau, RJ. 1961. Biology of Eggs and Implantation. Page 831-838 In: Sex and Internal Secretions. Volume 2. W. Young, ed. Waverly Press, Baltimore, MD.

Bursal, CA. 1999. Embryogenesis, mammalian. Page 1030 In: Encyclopedia of Reproduction. Volume 1. E. Knobil, and JD. Neill; Academic Press, New York, NY.

Chami, O, A Megevand, T Ott, F Bazer, C O’Neill. 1999. Platelet-activating Factor May Act as an Endogenous Pulse Generator for Sheep of Luteolytic PGF2-alpha Release. American Journal of Physiology. 276 (Endocrinol. Metabol. 39), 
E783-E792.

Chaouat, G, Menu E, DA Clark, M Dy, M Minkowski, TG Wegmann. 1990.

Control of fetal survival in CBA X DBA/2 mice by lymphokine therapy. Journal of Reproduction and Fertility. 80: 447-458.

Costine, BA, BL Sayre, EK Inskeep. 2001. Embryotoxicity of Regressing Corpora Lutea In Ewes. Reproduction. 122: 883-887.

Dalton, T, K Kover, SK Dey, GK Andrews. 1994. Analysis of the Expression of Growth Factor, Interleukin-1, and Lactoferrin Genes and the Distribution of Inflammatory Leukocytes in the Preimplantation Mouse Oviduct. Biology of Reproduction. 51: 597-606.

Dekel, N. 1999. Meiotic Cell Cycle, Oocytes. Page 168-176 In: Encyclopedia of Reproduction. Volume 3. E. Knobil, and JD. Neill; Academic Press, San Diego, CA.

Dosiou, C, LC Giudice. 2005. Natural Killer Cells in Pregnancy and Recurrent Pregnancy Loss: Endocrine and Immunologic Perspectives. Endocrine Reviews. 26: 44-62.

Duclos, AJ, EK Haddad, MG Baines. 1995. Presence of Activated Macrophages in a Murine Model of Early Embryo Loss. American Journal of Reproductive Immunology. 33: 354-366.

Dziarski, R. 1997. Relationships Between Adjuvant, Immnosuppressive, and Mitogenic Activities of Staphylococcal Peptidoglycan. Infection and Immunity. 26: 508-514.

Erlebacher, A, D Zhang, AF Parlow, LH Glimcher. 2004. Ovarian Insufficiency and Early Pregnancy Loss Induced by Activation of the Innate Immune System. The Journal of Clinical Investigation. 114: 39-48.

Fortunato, SJ, SJ Lombardi, R Menon. 1998. Immunoreactivity of Human Fetal Membranes to Peptidoglycan-Polysaccharide (PG-PS): Cytokine Response Journal of Perinatal Medicine. 26: 442-447.

Ganz, T, V Gabayan; HI Liao; L Liu; A Oren; T Graf; AM Cole. 2003. Blood. 101: 2388-2392.

Gendron, RL, FP Nestel; WS Lapp; MG Baines. 1990. Lipopolysaccharide-Induced Fetal Resorption in Mice is Associated with the Intrauterine Production of Tumor Necrosis Factor-Alpha. Journal of Reproduction and Fertility. 90: 395-402.

Goodman, RL, EK Inskeep. 2006. Neuroendocrine Control of the Ovarian Cycle of the Sheep. Page 2416-2418 in Knobil and Neill's Physiology of Reproduction. Third 
Edition. J. Neill, ed. Academic Press, San Diego, CA.

Haddad, EK, AJ Duclos, WS Lapp, MG Baines. Early Embryo Loss is Associated with The Prior Expression of Macrophage Activation Markers in the Decidua. The Journal of Immunology. 158: 4886-4892.

Hansen, PJ, P Soto, RP Natzke. 2004. Mastitis and Fertility in Cattle-Possible Involvement of Inflammation or Immune Activation in Embryonic Mortality. American Journal of Reproductive Immunology. 51: 294-301.

Holaskova, I. 2002. Effect of Peptidoglycan-Polysaccharide Complex on Reproductive Efficiency and Mastitis in Sheep. Master Thesis. West Virginia University.

Holaskova, I, GS Lewis, M Elliot, KP Blemings, RA Dailey. 2004. Effect of Peptidoglycan-Polysaccharide Complex on Reproductive Efficiency in Sheep. American Journal of Reproductive Immunology. 52: 197-203.

Hockett, ME, RA Almeida, NR Rohrbach, SP Oliver, HH Dowlen, FN Schrick. 2005. Effects of Induced Clinical Mastitis During Preovulation on Endocrine and Follicular Function. Journal of Dairy Science. 88: 2422-2431.

Hunt, JS, HL Chen, L Miller. Minireview: Tumor Necrosis Factors: Pivotal Components Of Pregnancy. Biology of Reproduction. 54: 554-562.

Inskeep, E.K., Lewis, P., Stilley, N., Mulledy, R., and Dinsmore, H. 1983. Synchronization of Estrus As a Management Tool in the Ewe Flock. West Virginia University Agricultural and Forestry Experiment Station. Circular 128. 7 pgs. West Virginia University, Morgantown.

Inskeep, EK, RA Dailey. 2005. Embryonic Death in Cattle. The Veterinary Clinics of North America. Food Animal Practice. 21: 437-461.

Janeway, CA, P Travers. M Walport, M Shlomchik. 2001. In: Immunobiology: the immune system in health and disease. $5^{\text {th }}$ ed. P. Austin, E. Lawrence eds. Garland Publishing, New York, N.Y.

Kahl, S, TH Elsasser. 2005. Exogenous testosterone modulates tumor necrosis factoralpha and acute phase protein responses to repeated endotoxin challenge in steers. Domestic Animal Endocrinology

Keisler, DH, ML Andrews; RJ Moffatt. 1992. Subclinical Mastitis in Ewes and Its Effect on Lamb Performance. Journal of Animal Science. 70:1677-1681.

Kirk, JH. 2006. Infectious Abortions in Dairy Cows. UC Davis Veterinary Medicine Extension. http://www.vetmed.ucdavis.edu/vetext/INF-DA/Abortion.html. Lee Laboratories 1997. Technical Data Sheet. PG-PS 100P. Grayson, Georgia. 
Leslie, KE, WTK Bosu, K Lissemore, D Kelton. 1986. The Effects of Gonadotrophin Releasing Hormone Administration Four Days After Insemination on FirstService Conception Rates and Corpus Luteum Function in Dairy Cows. Canadian Journal of Veterinary Research. 50: 184-187.

Louca, A, JE Legates. 1968.Production Losses in Dairy Cattle Due to Days Open. Journal of Dairy Science. 51: 573-583.

Medzhitov, R, C Janeway. 2000. Innate immune recognition: mechanisms and pathways. Immunological Reviews. 173: 89-97.

Nakayama, T, S Sonoda, T Urana, T Yamada, M Okada. 1993. Monitoring Both Serum Amyloid Protein A and C-Reactive Protein as Inflammatory Markers in Infectious Diseases. Clinical Chemistry. 39: 293-297.

Ozinsky, A, DM Underhill, JD Fontenot, AM Hajjar, KD Smith, CB Wilson, L Schroeder, A Aderem. 2000. The Repertoire for Pattern Recognition of Pathogens by the Innate Immune System is Defined by Cooperation between Toll-like Receptors. Proceedings of the National Academy of Sciences of the United States of America. 97: 13766-13771.

Paape, MJ, PM Rautianinen, EM Lilius, CE Malstrom, TH Elsasser. 2002. Development Of Anti-Bovine TNF-Alpha mAB and ELISA for Quantitating TNF-Alpha in Milk After Intramammary Injection of Endotoxin. Journal of Dairy Science. 85: 765-773.

Pampfer, S, I Vanderheyden, J Vesela, RD Hertogh. 1995. Neutralization of Tumor Necrosis Factor-Alpha Action on Cell Proliferation in Rat Blastocysts by Antisense Oligodeoxyribonucleotides Directed Against TNF-alpha p60 Receptor. Biology of Reproduction. 52: 1316-1326.

Paria, BC; H Song; SK Dey. 2001. Implantation: Molecular Basis of Embryo-Uterine Dialogue. The International Journal of Developmental Biology. 45: 597-605.

Pioli, PA, E Amiel, TM Schaefer, JE Connolly, CR Wira, PM Guyre. 2004. Differential Expression of Toll-like Receptors 2 and 4 in Tissues of the Human Female Reproductive Tract. Infection and Immunity. 72: 5799-5806.

Pyorala, S. 2002. New Strategies to Prevent Mastitis. Reproduction in Domestic Animals. 37: 211-216.

Quinlivan, TD, CA Martin, WB Taylor, IM Cairney. 1966. Estimates of Pre- and Perinatal Mortality in the New Zealand Romney Marsh Ewe. Journal of Reproduction and Fertility. 11: 391-398. 
Robertson, SA, TG Wegmann. 1994. The Role of Cytokines in Gestation. Critical Reviews in Immunology. 14: 239-292.

Rosenthal, S, and R Diziarski. 1994. Isolation of Peptidoglycan and Soluble Peptidoglycan Fragments. Methods in Enzymology. 235: 253-285.

Rotta, J. 1975. Endotoxin-like properties of the peptidoglycan. Z. Immun.-Forsch. Bd. 149: 230-244.

Sasaki, K, Z Ma, TS Khatlani, M Okuda, H Inokuma, T Onishi. 2003. Evaluation of Feline Serum Amyloid A as an Inflammatory Marker. Journal of Veterinary Medicine and Science. 65: 545-548.

Seals, RC, MC Wulster-Radcliffe, GS Lewis. 2002. Modulation of the Uterine Response to Infectious Bacteria in Postpartum Ewes. American Journal of Reproduction. 47: 57-63.

Senger, PL. 1999. Placentation, the endocrinology of gestationand parturition. In: Pathways to Pregnancy and Parturition. Second Edition. Current Conceptions, Inc., Pullman, Washington, p. 236.

Schrick, FN, ME Hockett, AM Saxton, MJ Lewis, HH Dowlen, SP Oliver. 2001.Influence of Subclinical Mastitis During Early Lactation on Reproductive Parameters. Journal of Dairy Science. 84: 1407-1412.

Silver, RM, SW Lohner, RA Daynes, MD Mitchell, DW Branch. 1994. Lipopolysaccharide-Induced Fetal Death: The Role of Tumor-Necrosis Factor Alpha. Biology of Reproduction. 50: 1108-1112.

Sordillo, LM, K Shafer-Weaver, D DeRosa. 1997. Symposium: Bovine Immunology; Immunobiology of the Mammary Gland. Journal of Dairy Science. 80: 18511865.

Stewart, AB, EK Inskeep, EC Townsend, RA Dailey. 2003. Effects of Gram-Positive Bacterial Pathogens in Ewes: Peptidoglycan as a Potential Mediator of Interruption of Early Pregnancy. Reproduction. 125: 295-299.

Stott, GH, RJ Williams. 1962. Cause of Decreased Breeding Efficiency in Dairy Cattle Associated with Seasonally High Temperatures. Journal of Dairy Science. 45: 1369-1375.

Supajatura, V, H Ushio, A Nakao, S Akira, K Okumura, C Ra, H Ogawa. 2002. The Journal of Clinical Investigation. 109: 1351-1359.

Swartz, HA. 2001. Mastitis in the ewe. University of Missouri Extension at: http://www.case-agworld.com/cAw.LUmast.html /August 2002/ 
Takeuchi, O, T Kawai, PF Muhlradt, M Morr, JD Radolf, A Zychlinsky, K Takeda, S Akira. 2001. Discrimination of Bacterial Lipoproteins by Toll-like Receptors. International Immunology. 13: 933-940.

Thatcher, WW, CR Staples, G Danet-Desnoyers, et al. 1994. Embryo Health and Mortality in sheep in cattle. Journal of Animal Science. (Suppl 3): 16-30.

Underhill, DM, A Ozinsky, KD Smith, A Aderem. 1999. Toll-like receptor-2 mediates Mycobacteria-induced Proinflammatory Signaling in Macrophages. 1999. Proceedings of the National Academy of Sciences of the United States of America. 96: 14459-14463.

Vogels, MTE, L Cantoni, M Carelli, M Sironi, P Ghezzi, JWM Van Der Meer. 1993. Role of Acute-Phase Proteins in Interleukin-1-Induced Nonspecific Resistance to Bacterial Infections in Mice. Antimicrobial Agents and Chemotherapy. 37: 2527-2533.

Wang, ZM, C Liu, R Dziarski. 2000. Chemokines are the main proinflammatory mediators in human monocytes activated by Staphylcoccus aureus, peptidoglycan, and endotoxin. The Journal of Biological Chemistry. 275: 20260-20267. 